\title{
Micro-dose Paranasal Computed Tomography is Valuable When Evaluating Diseases of the Paranasal Sinuses
}

\author{
Paranazal Sinüs Hastalıklarını Değerlendirirken Mikro-doz Paranazal Sinüs \\ Bilgisayarlı Tomografinin Değeri \\ ๑ Mustafa Özbayrak, ๑ Burak Ertaş*, ๑ Özden Sila Ulus**, ๑ Alper Özdilek, \\ - Ercan Karaarslan* \\ istanbul University Cerrahpaşa Faculty of Medicine, Department of Radiology, İstanbul, Turkey \\ ${ }^{*}$ Acıbadem Maslak Hospital, Clinic of Otorhinolaryngology, Istanbul, Turkey \\ **Acıbadem Mehmet Ali Aydınlar University Faculty of Medicine, Department of Radiology, Istanbul, Turkey
}

Abstract

Aim: We explored whether a reduction in the radiation dose affected the quality of diagnostic images generated using third-generation dualsource computed tomography (CT) running advanced third-generation iterative reconstruction software.

Methods: From February to May 2015, 72 consecutive patients aged 16 to 64 years with clinically suspected sinusitis were randomly and prospectively enrolled and divided into two groups (standard or micro-dose (T). Anatomical landmarks and mucosal structures were independently evaluated by a radiologist and an otorhinolaryngologist using a four-point grading scale. Mean scores were calculated and compared.

Results: All images were of diagnostic quality. The mean effective radiation dose was significantly lower in patients evaluated via the micro-dose protocol (group 2) than in those evaluated using the standard protocol (group 1) $(p<0.05)$. The mean anatomical scores showed that all landmarks were very well-defined, with the exceptions of the uncinate attachment point and the ethmoid foramen (used to identify the ethmoid artery). The Wilcoxon signed rank test revealed no significant difference between the mean scores of the two observers for either group ( $p>0.05)$.

Conclusion: The radiation dose to the paranasal sinus delivered during CT in patients with suspected sinusitis can be reduced to $0.003 \mathrm{mSv}$ using third-generation dual-source CT running advanced iterative reconstruction software.

Keywords: Paranasal sinus, radiation, computed tomography, microdose
Amaç: Radyasyon dozunda azalma sağlayan üçüncü nesil çift kaynaklı bilgisayarlı tomografi (BT) kullanılarak oluşturulan ve üçüncü nesil yeniden yapılandırma yazılımı desteği ile geliş̧irilen görüntülerin, tanısal görüntü kalitesini etkileyip etkilemediğini araştırdık.

Yöntemler: Şubat-Mayıs 2015 tarihleri arasında klinik olarak sinüzit ön tanısı alan 16-64 yaşları arasında ki 72 hasta rastgele ve prospektif olarak çalışmaya alındı. Hastalar rastgele iki gruba ayrıldı ve standart ya da mikro-doz BT değerlendirmesi yapıldı. Anatomik işaretler ve mukozal yapılar, bir radyolog ve bir kulak burun boğaz uzmanı tarafından dört noktalı bir derecelendirme ölçeği kullanılarak bağımsız olarak değerlendirildi. Ortalama puanlar hesaplandı ve karşılaştırıldı.

Bulgular: Tüm görüntüler tanı kalitesinde idi. Ortalama etkili radyasyon dozu, mikro doz protokolü (grup 2) ile değerlendirilen hastalarda standart protokol (grup 1) kullanılarak değerlendirilenlerden anlamlı olarak daha düşüktü $(p<0,05)$. Ortalama anatomik skorlar, unsinat bağlantı noktası ve etmoid foramen (etmoid arteri tanımlamak için kullanıldı) hariç diğer tüm noktaların çok iyi tanımlanmış olduğunu gösterdi. Wilcoxon işaretli sıra testi, her iki grup için iki gözlemcinin ortalama puanları arasında anlamlı bir fark olmadığını ortaya koymuştur $(p>0,05)$.

Sonuç: Sinüzitten şüphelenilen hastaların çekilen $\mathrm{BT}^{\prime}$ sinde uygulanan radyasyon dozu, ileri rekonstrüksiyon yazılımı destekli üçüncü jenerasyon çift-kaynaklı BT kullanılarak 0,003 mSv'ye indirilebilmektedir.

Anahtar Sözcükler: Paranazal sinüs, radyasyon, bilgisayarlı tomografi, mikro-doz
Address for Correspondence/Yazışma Adresi: Burak Ertaş

Acıbadem Maslak Hospital, Clinic of Otorhinolaryngology, İstanbul, Turkey

Phone: +90 2123044298 E-mail: drbertas@yahoo.com ORCID ID: orcid.org/0000-0002-5347-3878

Received/Geliş Tarihi: 31 July 2018 Accepted/Kabul Tarihi: 28 August 2018
Copyright 2019 by The Medical Bulletin of istanbul Haseki Training and Research Hospital The Medical Bulletin of Haseki published by Galenos Yayinevi. ${ }^{8}$ Telif Hakkı 2019 istanbul Haseki Eğtim ve Araşurrma Hastanesi Haseki Tip Bülteni, Galenos Yaynevi tarafindan yaynlanmıştr. 


\section{Introduction}

Computed tomography (CT) of the paranasal sinus is becoming a routine imaging method for patients with inflammatory, paranasal sinus disease $(1,2)$. CT identifies anatomical variations that may influence planned surgical procedures. Radiation exposure during $\mathrm{CT}$ has been of major concern. When the paranasal sinuses are imaged, tissues that are particularly sensitive to radiation (e.g., the thyroid and the visual lenses) may be exposed to direct or scattered X-ray beams. Thus, the X-ray dose during paranasal sinus CT should be as low as possible (3-6). Ongoing concerns about the radiation-related risks of cancer development have caused radiological societies to recommend that the $\mathrm{CT}$ radiation dose should be reduced to a level that is "as low as reasonably achievable." Modern third-generation dual-source CT scanners running iterative reconstruction (IR) software allow significant reductions in the radiation dose. To the best of our knowledge, the dose level that we show (in our present study) to be adequate for paranasal CT (0.003 mSv) is the lowest effective dose associated, to date, with no significant loss of diagnostic image quality. We term this dose a "micro-dose."

\section{Methods}

From February to May 2015, 72 consecutive patients (33 females, 39 males) with clinically suspected sinusitis were prospectively included. The mean patient age was 36.5 years (range, 16-64 years). Our study was approved by our hospital's Ethics Committee, and all the patients signed informed consent forms. The patients were randomly divided into two groups; standard and microdose CT groups. The age and gender distribution were similar (Table 1). All CT scans were performed with the aid of a third-generation dual-source multidetector scanner (SOMATOM Force; Siemens Healthcare AG, Erlangen, Germany). Scans were acquired in the axial plane running from the highest point of the frontal sinus to the maxillary sinus, with the upper jaw adjusted to the gantry to reduce dental artifacts. The field of view was sufficiently broad to encompass the facial bones, the mastoid area, and the paranasal sinuses. Scans were acquired in a cranialto-caudal direction. The collimation was $0.6 \mathrm{~mm}$ for both groups; the pitches were 0.8 and $3.2^{\circ}$, respectively; and the rotation times were 1 and $0.25 \mathrm{~s}$, respectively. The tube voltages and currents were $90 \mathrm{kV} / 63 \mathrm{~mA}$ and 70 $\mathrm{kV} / 52 \mathrm{~mA}$, respectively (Table 2 ). All CT images were processed from the raw data using advanced model-based software (ADMIRE; level 3). We created $3 \mathrm{~mm}$ thick slices at $3 \mathrm{~mm}$ slice distances in the axial (bone and soft tissue kernels), sagittal, and coronal (bone kernel) planes.

Ethical committee approval of our study was discussed by the Acıbadem University Ethical Committee at the Atadek Committee Meeting dated 02.06.2015 and numbered 2015/7, therefore, it was found to be appropriate in terms of medical ethics with the decision number 2015-7/5.

\section{Image Quality Assessment}

Subjective image quality was independently assessed by a radiologist and an otolaryngologist using a four-point scale $(0=$ the structure could not be recognized, $1=$ the structure was vaguely characterized, $3=$ the structure was moderately characterized, and $4=$ the structure was well-characterized). Mucosal pathologies and significant anatomical points were also assessed. The anatomical milestones scored were the back walls of the frontal sinuses, the medial walls of the maxillary sinuses, the orbital base and the medial wall of the orbit, the bony surfaces of the sphenoid sinuses, the infundibulum, the Keros classification, the uncinate processes, the uncinate attachment point, and the course of the anterior ethmoidal artery. The researchers evaluated opacification of the sinuses, non-specific mucosal pathologies, fluid accumulations (with the air-fluid levels), polyps, and retention cysts. Normal and pathological mucosal structures of the frontal, maxillary, ethmoid, and sphenoid sinuses were additionally assessed. Mean scores were calculated and compared.

\section{Estimation of Radiation Doses}

The scanner console gave the dose-length product [Data loss prevention (DLP); mGy.cm], the CT dose index (CTDI $\left.{ }_{\text {vol }} ; \mathrm{mGy}\right)$, and the scan length. The DLP was used as a measure of radiation exposure. All DLPs were archived in the examination reports. Following the

\begin{tabular}{|l|l|}
\hline \multicolumn{2}{|l|}{ Table 1. Sex and age characteristics of groups } \\
\hline Group $\mathbf{1}$ & Group $\mathbf{2}$ \\
\hline 17 females, 19 males & 16 females, 20 males \\
\hline $16-64(39.2 \pm 10.4)$ years & $17-50(33.8 \pm 8.63)$ years \\
\hline
\end{tabular}

\begin{tabular}{|l|l|l|}
\hline \multicolumn{3}{|l|}{ Table 2. Scan parameters and calculated radiation doses } \\
\hline & Group 1 & Group 2 \\
\hline Tube collimation (mm) & 0.6 & 0.6 \\
\hline Tube voltage (kV) & 90 & 70 \\
\hline $\begin{array}{l}\text { Quality tube current-time } \\
\text { product (mAs) }\end{array}$ & 63 & 52 \\
\hline Rotation time (sec) & 1 & 0.25 \\
\hline Pitch & 0.8 & 3.2 \\
\hline DLP (mGy.cm) & 55.76 & 1.35 \\
\hline Effective dose (mSv), mean (SD) & $0.128 \pm 0.031$ & $0.003 \pm 0.001$ \\
\hline $\begin{array}{l}\text { kV: kilovolts, mAs: milliampere-seconds, DLP: Dose-length product, mGy.cm: } \\
\text { miligray.centimeters, mSv: Milisievert }\end{array}$ \\
\hline
\end{tabular}


European guideline, we used a conversion coefficient of $0.0023 \mathrm{mSv} / \mathrm{mGy} . \mathrm{cm}$ to compute dosage (7).

\section{Statistical Analysis}

Statistical analysis was performed with the aid of SPSS version 21.0 for Windows (SPSS, IBM, USA). Values are presented as means \pm standard deviations and ranges. The average scores of the two observers were compared using the Wilcoxon signed rank test. A p value of less than 0.05 was considered to indicate statistical significance; all tests were two-sided. The subjective image quality scores were compared using Cohen's kappa index.

\section{Results}

The two groups did not differ significantly in terms of either age or gender distribution ( $p>0.05$ ). All CT procedures yielded images of diagnostic quality. The mean effective radiation dose was significantly lower when the micro-dose (group 2) rather than the standard protocol (group 1) was employed $p<0.05$ (Table 2). In terms of significant anatomical points, the mean scores for the back walls of the frontal sinuses, the medial walls of the maxillary sinuses, the orbital base and medial wall, the bony surfaces of the sphenoid sinuses, the infundibulum, the Keros classification, and the uncinate processes were all well-characterized (Figure 1). The ethmoid foramen (a marker of the course of the anterior ethmoidal artery) and the uncinate attachment point were either vaguely or moderately characterized in group 2 but well-characterized in group 1. In terms of mucosal changes in the paranasal sinuses, both normal and pathological mucosae were well-characterized in both groups (Figure 2). The mean scores of the two researchers were compared using Wilcoxon's signed-rank test; no significant difference was apparent for either group ( $p>0.05)$. Both inter-and intraobserver agreement was excellent (the $K$ values ranged from 0.80 to 1 ).
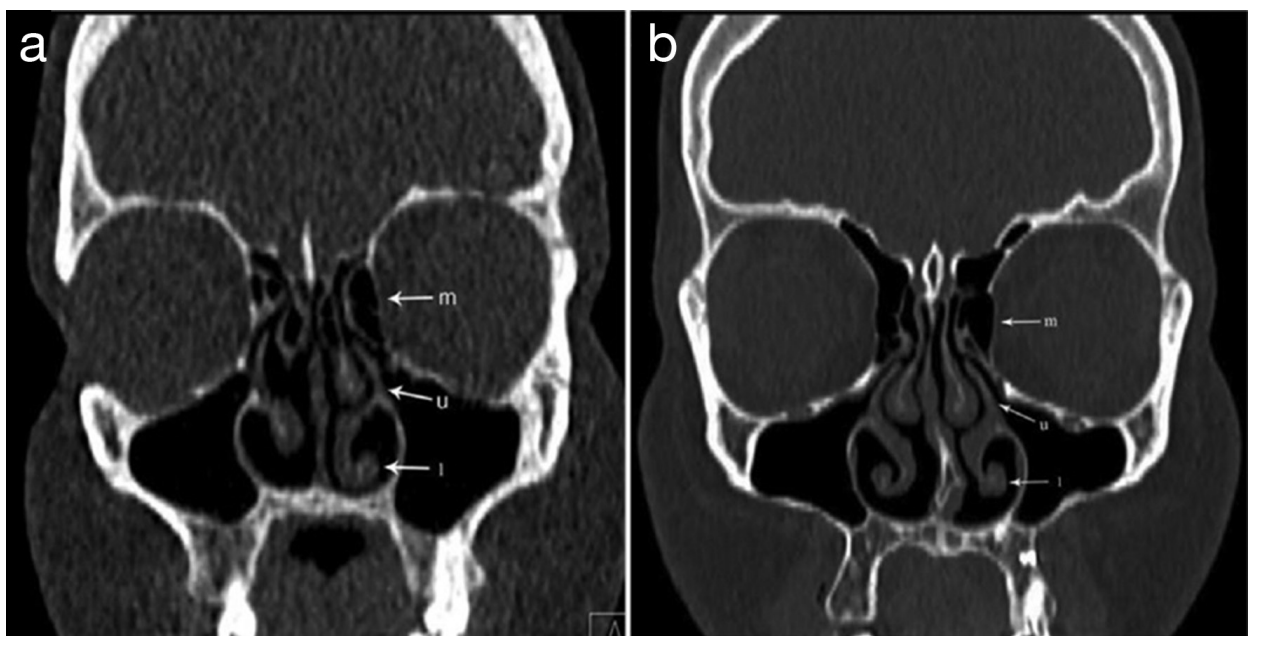

Figure 1. Coronal paranasal computed tomography images of a patient (group 1) (a) evaluated using the micro-dose protocol and a patient (group 2) (b) evaluated using the standard protocol, indicating the uncinate process (U), the medial wall of the maxillary sinus $(\mathrm{M})$, and the inferior turbinate (I)
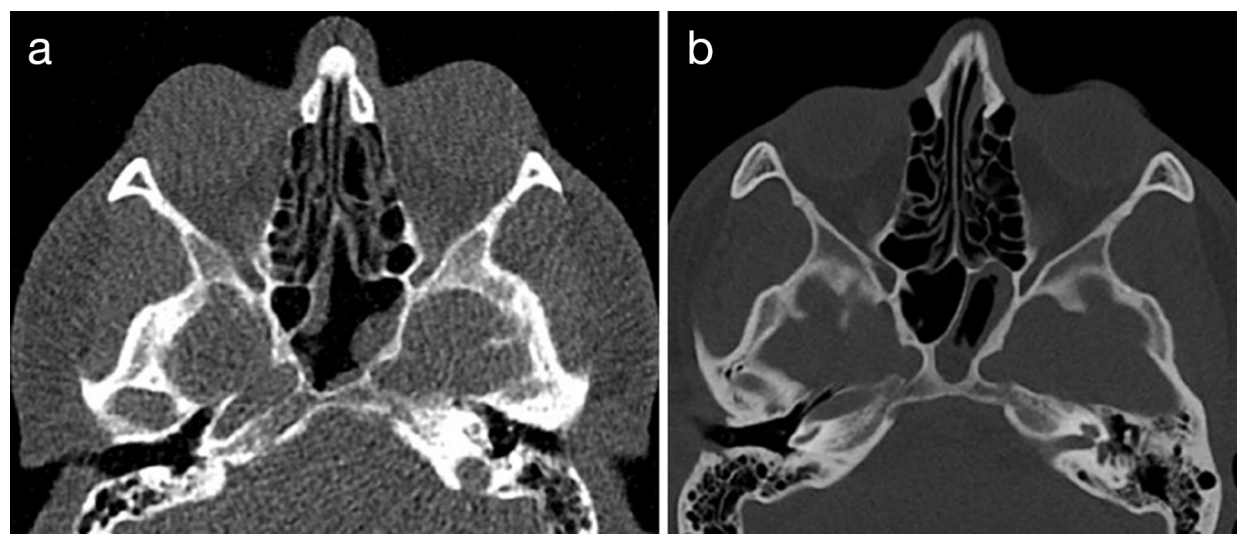

Figure 2. Axial paranasal computed tomography images taken at the level of the sphenoid sinus using an appropriate window. Images from a 39-year-old male examined using the micro-dose protocol (group 2) (a) and a 34-year-old male examined using the standard protocol (group 1) (b) Sinusitis with mucus membrane swelling is evident in the left region of the sphenoid sinus of both patients 


\section{Discussion}

Over the past 10 years, radiation-based imaging of the paranasal sinuses has progressed from plain $X$-ray to $C T$; the latter procedure is now routine when investigating inflammatory, paranasal sinus disease. CT reveals inflammation, bones, soft tissues, and anatomical variations thereof in detail. The increased use of $C T$ is associated with radiation exposure; this is of particular concern in pediatric patients. The thyroid and visual lenses are particularly susceptible to radiation delivered during repeat head and cervical CT (8). Thus, optimization of CT parameters is a major concern of diagnostic radiology. Currently, efforts are underway to minimize the radiation dose during $\mathrm{CT}$ of the paranasal sinuses without compromising diagnostic reliability (3-5). Most studies have sought to reduce tube voltage and current and increase the pitch $(3,6,9)$. A radiation dose of 0.76 $\mathrm{mSv}$ was reportedly effective (10). The effective doses of reduced-dose protocols have ranged from 0.05 to 0.48 mSv $(11,12)$.

We recently used second-generation dual-source CT (Somatom Definition Flash; Siemens Healthcare, Forchheim, Germany) to show that low-dose high-pitch protocols permitted significant dose reductions without any loss in diagnostic image quality (13). Even when the dose was reduced to $0.019 \mathrm{mSv}$, the image quality was adequate to allow important anatomical and mucosal structures to be visualized. In the present study, we used a third-generation dual-source CT scanner. The Somatom Force features new Vectron X-ray tubes and Stellar Infinity detectors. The Vectron tube has a very large anode and can accommodate very short exposure times because the permissible heat load is high. Unlike the second-generation dual-source platform, the more recent platform can accommodate two photon shields; these are tin filters (TFs) positioned before either X-ray tube; the positions of the TFs can be altered. This facilitates single-energy scanning. Also, third-generation dual-source CT contains inbuilt software permitting IR, specifically, advanced model-based IR (ADMIRE). This uses an iterative approach toward statistical modeling in the raw data space with noise detection in the imaging domain. IR is used during image reconstruction to reduce noise in $\mathrm{CT}$ data obtained at lower radiation doses (14). Thus, IR in the image space (IRIS; Siemens, Erlangen, Germany) allows the dose required for paranasal sinus $C T$ to be reduced without compromising image quality (2). More recently, sinogramaffirmed IR (SAFIRE; Siemens) has further reduced noise in paranasal sinus $C T$ images at the cost of some reduction in image quality (15).

Dual-source techniques allow the use of high pitches (up to 3.2) and yield gapless information sets, the diagnostic image quality of which is reliable as judged by various assessments (16). When the dual-source mode is accompanied by a high table feed, artefacts caused by patient movements are rendered largely irrelevant. Reliable data can be obtained from even distressed patients. Notably, use of a high-pitch mode means that younger patients may not need repeated scans, which is advantageous (3). We found that the accepted effective dose of $0.128 \mathrm{mSv}$ for group 1 patients could be reduced by $97.5 \%$, to $0.003 \mathrm{mSv}$ (group 2 patients). This did not compromise the observer scores or diagnostic image quality, as the group 2 images revealed the significant anatomical landmarks and mucosal abnormalities.

Plain radiography (three or two views; the latter posterior-anterior and lateral) was associated with mean radiation exposures of 0.098 and $0.058 \mathrm{mSv}$ (12), slightly lower than the standard CT dose $(0.128 \mathrm{mSv})$ of our study (group 1). However, our proposed micro-dose CT exposure (0.003 mSv) (group 2) was 32-fold lower than that associated with three plain radiographic views and 19-fold lower than that of two such views. We agree with the view presented in the literature that plain radiography does not adequately evaluate complex anatomical and mucosal abnormalities of the paranasal sinuses; indeed, such radiography should be avoided whenever possible. Cone-beam $\mathrm{CT}(\mathrm{CBCT})$, originally introduced to facilitate dental procedures, is an alternative imaging modality for sinusitis (17). Scattered irradiation of (especially) the thyroid is lower upon CBCT than multislice CT (18). However, recent developments in $C T$ technology allow paranasal sinus assessment using much lower radiation doses than $\mathrm{CBCT}$. Further studies of the image qualities afforded by $C B C T$ and low-dose $C T$ are required.

We found that a reduction in the radiation dose did not diminish diagnostic reliability. Both typical and pathological mucosal structures were identified in the paranasal sinuses of both groups. The important anatomical structures were generally very well-defined, except for the uncinate attachment point and the ethmoid foramen (a marker of the anterior ethmoidal artery) in group 2. We believe that standard dosing protocols should be established for depiction of bones and vascular structures (this is imperative for preoperative assessment). However, if sinusitis is the principal concern, as in the present study, our new micro-dose protocol is optimal.

\section{Study Limitations}

Our study had certain limitations. We did not quantify noise. Third-generation dual-source CT running ADMIRE significantly reduces image noise and yields the precise attenuations of materials varying greatly in density. Also, variation of window settings may reduce subjective noise without any loss of contrast (by reference to high-contrast 
bone). Second, we did not consider differences in patient size or weight. We believe that this was not a serious limitation as the structure of the paranasal sinus does not vary greatly among adults. We found that a CT current of $52 \mathrm{~mA}$ was satisfactory. It may be possible to further reduce the current without compromising image quality; this requires further study.

\section{Conclusion}

In conclusion, we believe that the radiation dose to the paranasal sinuses delivered via CT to patients with suspected sinusitis can be reduced to $0.003 \mathrm{mSv}$ using third-generation dual-source platforms running advanced IR software; this preserves the quality of diagnostic imaging, albeit with a slight decrease in subjective quality.

\section{Authorship Contributions}

Surgical and Medical Practices: M.Ö., B.E., A.Ö. Concept: M.Ö., B.E., E.K. Design: M.Ö., B.E., Ö.S. Data Collection or Processing: M.Ö., B.E., A.Ö., S.Ö. Analysis or Interpretation: A.Ö., S.Ö. Literature Search: M.Ö., B.E. Writing: M.Ö., B.E.

Conflict of Interest: No conflict of interest was declared by the authors.

Financial Disclosure: The authors declared that this study received no financial support.

\section{References}

1. Dammann F. Imaging of paranasal sinuses today. Radiologie 2007;47:578-83.

2. Bulla $S$, Blanke $P$, Hassepass $F$, et al. Reducing the radiation dose for low-dose CT of the paranasal sinuses using iterative reconstruction: feasibility and image quality. Eur J Radiol 2012;81:2246-50.

3. Schulz B, Potente S, Zangos S, et al. Ultra-low dose dualsource high-pitch computed tomography of the paranasal sinus: diagnostic sensitivity and radiation dose. Acta Radiol 2012;53:435-40.

4. Schell B, Bauer RW, Lehnert T, et al. Low-dose computed tomography of the paranasal sinus and facial skull using a high-pitch dual-source system-first clinical results. Eur Radiol 2011;21:107-12.

5. Brem MH, Zamani AA, Riva R, et al. Multidetector CT of the paranasal sinus: potential for radiation dose reduction. Radiology 2007;243:847-52.
6. Karabulut N, Akti U, Kazil S. Comparison of low dose and standard dose CT in the evaluation of inflammatory diseases of paranasal sinuses. Tani Girisim Radyol 2003;9:315-20.

7. Bongartz G, Golding SJ, Jurik AG, et al. European guidelines on quality criteria for computed tomography. Available at: http://www.drs.dk/ guidelines/ct/quality/. Accessed July 7, 2014.

8. Czechowski J, Janeczek J, Kelly G, et al. Radiation dose to the lens in sequential and spiral CT of the facial bones and sinuses. Eur Radiol 2001;11:711-3.

9. Kalender WA, Buchenau S, Deak P, et al. Technical approaches to the optimisation of CT. Phys Med 2008;24:71-79.

10. Tack D, Widelec J, De Maertelaer $V$, et al. Comparison between low-dose and standard-dose multidetector CT in patients with suspected chronic sinusitis. AJR Am J Roentgenol 2003;181:939-44.

11. Damilakis J, Prassopoulos P, Mazonakis M, et al. Tailored low dose three- dimensional CT of paranasal sinuses. Clin Imaging 1998;22:235-9.

12. Abul-Kasim K, Strömbeck A, Sahlstrand-Johnson P. Low-dose computed tomography of the paranasal sinuses: radiation doses and reliability analysis. Am J Otolaryngol 2011;32:4751.

13. Aksoy EA, Ozden SU, Karaarslan E, et al. Reliability of highpitch ultra-low-dose paranasal sinus computed tomography for evaluating paranasal sinus anatomy and sinus disease. J Craniofac Surg 2014;25:1801e4.

14. Gordic S, Morsbach F, Schmidt B, et al. Ultralow-dose chest computed tomography for pulmonary nodule detection: first performance evaluation of single energy scanning with spectral shaping. Invest Radiol 2014;49:465e73.

15. Schulz B, Beeres M, Bodelle B, et al. Performance of iterative image reconstruction in $C T$ of the paranasal sinuses: a phantom study. AJNR Am J Neuroradiol 2013;34:1072-6.

16. Baumueller S, Alkadhi $H$, Stolzmann P, et al. Computed tomography of the lung in the high-pitch mode: is breath holding still required? Invest Radiol 2011;46:240-5.

17. Zoumalan RA, Lebowitz RA, Wang $E$, et al. Flat panel cone beam computed tomography of the sinuses. Otolaryngol Head Neck Surg 2009;140:841-4.

18. Schulze $D$, Heiland $M$, Thurmann $H$, et al. Radiation exposure during midfacial imaging using 4- and 16-slice computed tomography, cone beam computed tomography systems and conventional radiography. Dentomaxillofac Radiol 2004;33:83-6. 